\title{
Leading Change
}

\section{The Role of the Principles for Responsible Management Education}

\author{
ANDREas Rasche AND MANUEl Escudero*
}

\section{1. 'Let's not waste a good crisis!'}

Without doubt, the context of responsible management education has changed over the last twelve months. Business schools ${ }^{1}$ are accused of being partly responsible for the current economic crisis because they have failed to seriously integrate reflections on ethical values into their curricula (Holland 2009; Jacobs 2009). Of course, we could lament more about the status of responsible management education (or rather the lack of much of a status). But why not take this crisis as an opportunity to lead change? Why not look into the future and use this crisis to finally champion responsible management education? While the economic downturn surely has remarkable negative effects on peoples' lives around the globe, it also creates a lot of promise, not least for the further dissemination and upscaling of responsible management education. The time is ripe for leading change with regard to responsible management education, in Germany and elsewhere. We are living in difficult and promising times, or as Ángel Cabrera (2009), President of Thunderbird School of Global Management, argued recently: "Let's not waste a good crisis!"

The argument which we would like to present here is as follows. When considering the changing context of responsible management education - mostly driven by the recent global economic downturn but also by a more general suspicion that business schools cannot deliver what they promise - we should not waste this opportunity to finally put responsible management education in its rightful place: at the strategic core of the business school curriculum. We propose to consider the Principles for Responsible Management Education (abbreviated PRME, pronounced 'prime') as one possible change agent to drive this process. The PRME embody a voluntary set of principles to which business schools can adhere in the interest of providing future leaders with the necessary insights and skills to reflect upon, critically analyze, and provide leadership with regard to corporate responsibility.

Dr. Andreas Rasche, Warwick Business School, The University of Warwick, CV4 7AL Coventry, United Kingdom, phone:+44-(0)24-7657-3131, e-mail: andreas.rasche@wbs.ac.uk; research interests: corporate responsibility and governance, United Nations Global Compact, responsible supply chain management. Dr. Manuel Escudero, Executive Director, Research Center for the Global Compact, Special Adviser to the United Nations Global Compact, and Director of International Academic Affairs, The Levin Institute, 116th East 55th Street, New York, New York, 10022, United States, phone: +1-(0)212-317-3534, e-mail: escuderom@unprme.org.

1 We use the word 'business school' throughout our discussion. This, however, should not indicate that our remarks are limited to business schools. In particular, the PRME can also be adopted by entire universities or universities of applied sciences. 


\section{A 'Window of Opportunity' to Champion Responsible Management Education}

We think there are at least two recent developments which should put responsible management education into the centre of business school's strategic positioning. From our perspective, both debates create a 'window of opportunity' to finally start integrating responsible management education into the curricula and research practices of business schools. We consider these developments to be as much of relevance for German academic institutions as they are for the rest of the world.

First, there is the discussion around whether business school education (or rather the lack of it) is to blame for the recent financial crisis. Of course, no one would seriously claim that academic institutions are exclusively responsible for the economic downturn. However, it cannot be neglected that business schools educated many of those people who contributed to the current crisis in one way or another. Many commentators raise doubts about whether business school education in general and MBA programs in particular adequately prepare students for the ethical challenges they face in their later careers. The Wall Street Journal, for instance, argues that business schools, by failing to systemically and critically discuss issues such as executive incentive programs, have contributed to the financial crisis (Jacobs 2009). Likewise, The New York Times wonders whether "the way business students are taught may have contributed to the most serious economic crisis in decades" (Holland 2009). The bottom line is that we cannot solely neglect that business schools have a responsibility to train their students in a responsible way. As James Post (2009) remarked recently in the Financial Times, "schools must now reinvent themselves as part of the solution".

Second, there is the argument that business schools" overemphasis on market mechanisms and the importance of companies' stock prices failed to teach students that they are part of a profession which is responsible for more than shareholder value (Khurana 2007). Management, as Khurana argues, is as much a profession as medicine or law. Business schools, however, never taught their students that they were part of a profession and thus expected to uphold basic ethical values. While it would be naïve to believe that professionalization of the management field would ipso facto make graduates more responsible, it is not unreasonable to suppose that a professionalization (e.g., expressed through a widely accepted code of conduct) could at least help to change business schools' culture and foster students' reflections. In other words, the current crisis has presented us, and the public at large, with the evidence that management carries with its decisions an important (positive or negative) social impact. In that sense, management is a profession that has to do with the common public good. Hence, infusing the sense of responsibility in future leaders and professionals about the social and environmental impact of management decision-making should be considered a central concern in business education from now on.

Related to this debate around the professional social risks of management decisionmaking, some schools are considering the introduction of an oath for managers. Thunderbird, for instance, introduced a 'Professional Oath of Honor' about four years ago. 


\begin{abstract}
"The Code has helped change our academic culture by shaping conversations inside and outside the classroom. We are yet to prove empirically whether the initiative will have a meaningful impact on the professional conduct of our graduates, but third party assessments indicate that our students may be more sensitive to the broader set of social responsibilities of managers than the average MBA student." (Cabrera 2009)
\end{abstract}

Trying to change education through a commitment to a set of aspirational/inspirational principles, like PRME, is as much needed as to give incentives for such a change through an 'oath' at the end of the educational period. Obviously, as in the debate some 20 years ago on quality control in the company, a final quality control does not preclude Total Quality Management throughout the entire production process. Thus, it is not only time to rethink what is being taught in business schools, but to also question the pillars upon which management education was built.

The two described developments are particularly interesting for German business schools as there has been a steep increase in MBA programmes over the last couple of years, either to meet rising local demand and/or to better position academic institutions in the increasingly competitive global business school landscape. While this development is certainly appreciable, there is also a risk that German business schools will more or less 'blindly' follow the traditional North American MBA model (with its overemphasis on teaching students how to handle hard data and come up with quick solutions; Mintzberg 2005). Considering the abovementioned 'window of opportunity' to champion and upscale responsible management education, German business schools should not waste this crisis to finally come to grips with integrating corporate responsibility issues into the curriculum. We believe that joining the global PRME network can support German business schools in building up capacity with regard to responsible management education, learning from the achievements and failures of other academic institutions, and thus being able to lead the change (instead of following it). Hence, the PRME should be perceived as one possible, yet by no means the only, way to building up a strategic approach towards responsible management education which clearly reaches beyond isolated courses on 'business ethics'.

\title{
3. One Answer- The PRME
}

The PRME reflect a change agent for responsible management education; a change agent which relies on the voluntary commitment of participating academic institutions. Similar to the United Nations Global Compact, the PRME are not a certification standard to ensure that a business school has complied with certain principles (Rasche 2009). Much like the Global Compact, the PRME, at the macro-level, provide a platform where interested institutions can exchange ideas and best practices, while, at the micro-level, they are supposed to stimulate and guide a school's development of responsible management education. The following six principles act as a 'walking stick' assisting those institutions which are willing to promote and champion responsible management education: 
(1) We will develop the capabilities of students to be future generators of sustainable value for business and society at large and to work for an inclusive and sustainable global economy.

(2) We will incorporate into our academic activities and curricula the values of global social responsibility as portrayed in international initiatives such as the United Nations Global Compact.

(3) We will create educational frameworks, materials, processes and environments that enable effective learning experiences for responsible leadership.

(4) We will engage in conceptual and empirical research that advances our understanding about the role, dynamics, and impact of corporations in the creation of sustainable social, environmental and economic value.

(5) We will interact with managers of business corporations to extend our knowledge of their challenges in meeting social and environmental responsibilities and to explore jointly effective approaches towards meeting these challenges.

(6) We will facilitate and support dialogue and debate among educators, business, government, consumers, media, civil society organizations and other interested groups and stakeholders on critical issues related to global responsibility and sustainability.

At first glance the six principles may look very general. However, it is essential to consider that there is a certain necessary contextual 'emptiness' when developing and implementing global principles because the contexts that business schools operate in may differ considerably (e.g., when looking at differences in legal systems and/or existing norms and values regarding education). Each participating institution needs to reflect upon (and thus show commitment to) what the six principles mean in practice. For example, the third principle regarding educational frameworks and learning materials can be implemented through quite different actions depending on factors such as class size and available resources (e.g., money to purchase case studies). At the same time, a whole new approach, experiential learning is being opened up in the context of PRME, and that debate will only progress through a process of exchange of best practices by leading PRME signatories. The point is to not believe that the six principles will tell educational institutions what to do, but to acknowledge that schools need to 'fill' these six principles with contextualized and innovative meaning based on reflections and peer discussions.

Participating institutions are expected to enter into a process of continuous improvement taking the six principles as a guiding idea about where to start and what to do. To inspire and foster mutual learning among institutions, the PRME require an annual reporting on progress. Reports are supposed to stimulate discussions, enable learning, disseminate ideas and allow participating institutions to set the agenda for responsible management education, both within organizations and in the wider socio-economic environment. It should also be pointed out that the PRME are not a membership initiative (i.e. an initiative which charges a membership fee in order to join the network). A key strength of principle-based initiatives, such as the Global Compact or the PRME, is that they allow for experimentation and innovation on the side of participants. As innovation cannot be regulated but evolves out of the commitment of participants, 
business schools should view the PRME as a step to finding and sharing new solutions and ideas towards responsible management education (Waddock et al. 2009).

The PRME grew in part because business leaders, who have committed themselves to the ten principles of the Global Compact, were asking educational institutions: What are you doing to help future business leaders to understand the challenges of responsible management? Any serious and long-term consideration of responsible management needs to include educational institutions as important players, particularly when reflecting upon the lessons we have learned from the recent financial crisis. Educational institutions not only provide factual knowledge about responsible business practices, but also (and maybe most importantly) have the ability to encourage students' reflection about their values. Considering this role of higher educational institutions, the PRME were developed between October 2006 and July 2007 by an international task force of 60 Deans, University Presidents, as well as scholars committed to the idea of responsible management education. To enhance the multi-stakeholder nature and perceived legitimacy of the development process, the drafting of the principles was supported by representatives from the United Nations Global Compact (UNGC), the Association to Advance Collegiate Schools of Business (AACSB), the Aspen Institute's Business and Society Program, the European Foundation for Management Development (EFMD), the Globally Responsible Leadership Initiative (GRLI), Net Impact, a student organization with more than 13,000 members, the Graduate Management Admission Council (GMAC), and the European Academy of Business in Society (EABIS). All of these institutions remain partners of the initiative as they are members of the steering committee which guides the PRME.

In July 2007, the outcome of this development process was presented to UN Secretary-General Ban Ki-moon at the triennial Global Compact Leaders Summit in Geneva. During its first two years of existence, the initiative witnessed a tremendous growth in terms of participating institutions (from around 40 in July 2007 to more than 270 in November 2009). The enormous interest in the PRME and its underlying idea was also reflected by the high participation rate in the first Global Forum for Responsible Management Education held at UN headquarters in December 2008.

\section{The PRME in Germany - The Benefits of Participation}

Whereas the initiative is currently approaching 270 signatories from all five continents, only twelve participating institutions are located in Germany. Hence, the PRME although a global success story to date - have not made it onto the agenda of most German business schools. We could speculate about possible reasons for this reservation to join the initiative (e.g., ranging from the historically weak position of 'business ethics education' in German universities to concerns about the Principles being perceived as constraining the traditionally important freedom of teaching and research within universities). Instead of speculating about possible constraints, we would like to highlight selected reasons for signing up to the initiative hoping to convince decision makers to think of the PRME as a change agent for their institutions.

First, any institution which joins the PRME enjoys the benefits of being a recognized leader with regard to responsible management education. The recent 'credit crunch' has shown that an adaptation process within the global economy is inevitable. This 
forecasts a 'race to the top' where the landscape of leading institutions will be reshaped, and where the leaders of the not too distant tomorrow will be those business schools who trigger a process of innovation and adaptation to the new environment, placing at the center of their educational activities the core values and concepts of sustainability and corporate social responsibility. This process will put corporate responsibility center stage and thus create more demand for ethics courses throughout the curriculum from students and potential employers alike. According to Blaine (2009), most schools have already witnessed a steep increase in ethics-related courses which has put responsible management education in its rightful place. The PRME can support and foster this process and help German academic institutions to be perceived as leaders in the field of responsible management education.

Second, the PRME can act as an internal change agent when trying to advance the curriculum in favour of a transversal updating of all disciplines, from finance to marketing, operations, human resources management or strategic management. As the principles need to be signed by the highest-ranking executive of a business school, it is reasonable to expect that 'after the signature' there should be some top-level support for pushing ethical issues into the curriculum. Considering the many micro-political struggles within business schools (e.g., between different departments), support and effective leadership from a high-ranking executive (e.g., the Dean) can help to overcome ideological barriers to create interest and acceptance for ethical issues within the faculty. This is not to say that the PRME need to be exclusively implemented in a topdown mode. Rather, the backing by high-ranking decision makers should support grassroots ideas coming from different parts of the faculty. Our findings, out of the experience gathered throughout the PRME community, clearly suggest that both a top-down approach and a bottom-up approach are necessary to make progress along the lines of PRME.

Third, joining the PRME gives access to a strong network of likeminded institutions. The $1^{\text {st }}$ Global Forum for Responsible Management Education, which was held in New York City in December 2008, demonstrated that committed schools have a lot to share and that access to this network can give a school a competitive edge in times where the business school landscape is becoming evermore competitive. Building capacity and being a leader in terms of responsible management education is increasingly rewarded through rankings such as the Aspen Institute's Beyond Grey Pinstripes list and Net Impact's Business as UNusual guide. Considering that German institutions are currently not listed in both rankings, the PRME should be perceived as a change agent to position an institution's efforts with regard to responsible management education in the global business school landscape. This process of 'catching up' also creates the opportunity to learn from best practices which other business schools have developed.

To conclude, we think there is a lot of promise when considering the current status of the PRME, particularly in view of the abovementioned changing context of management education in general. A growing number of business schools are recognizing the necessity to better integrate aspects of corporate responsibility into teaching and research, and the PRME are a necessary and timely initiative to support this process. We are positive that German business schools will play a significant role in shaping the future discussions and practices around responsible management education in general 
and the PRME in particular. Leading the necessary change requires accepting that responsible management has to be one key strategic concern of any business school which takes the lessons of the current crisis seriously. There could not be a better time than now to start refocusing business schools' agendas and practices.

\section{References}

Blaine, S. (2009): Crisis Means Boom Time for Business Ethics Courses, http://www.business day.co.za, last Accessed: 11 March 2009.

Cabrera, A. (2009): Let's Professionalize Management, http://blogs.harvardbusiness.org/howto-fix-business-schools/2009/04/a-hippocratic-oath-for-future.html, last accessed: 2 May 2009.

Holland, K. (2009): Is It Time to Retrain B-Schools?, http://www.nytimes.com/2009/03/15/ business/15school.html, last accessed: 15 March 2009.

Jacobs, M, (2009): How Schools Have Failed Business: Why not More Education on the Responsibility of Boards?, http://online.wsj.com/article/SB124052874488350333.html, last accessed: 2 May 2009.

Khurana, R. (2007): From Higher Aims to Hired Hands - The Social Transformation of American Business Schools and the Unfulfilled Promise of Management as a Profession, Princeton.

Mintzberg, H. (2005): Managers not MBAs, San Francisco.

Post, J. E. (2009): Never Waste a Crisis, http://www.ft.com/cms/s/2/486008e8-3669-11de -af40-00144feabdc0.html, last accessed: 4 May 2009.

Rasche, A. (2009): 'A Necessary Supplement': What the United Nations Global Compact Is (Not), in: Business \& Society, 48(4): forthcoming.

Waddock, S./ Rasche, A./ Werbane, P./ Unrub, G. (2009): The Principles for Responsible Management Education: Implementation and Assessment, in: Swanson, D. L./ Fisher, D. G.: Towards Assessing Business Ethics Education, Charlotte, NC: forthcoming. 